\title{
CO JEST STAWKĄ MOBILNOŚCI PRACY? GRANICE, MIGRACJE, WSPÓŁCZESNY KAPITALIZM ${ }^{1}$
}

\author{
SANDRO MEZZADRA
}

PRZELOŻYLI: PIOTR JUSKOWIAK I KRYSTIAN SZADKOWSKI

\begin{abstract}
Abstrakt: Prezentowany tekst rozpoczyna się od krótkiego omówienia kilku wpływowych badań na temat mobilności pracy w ramach historycznego i współczesnego kapitalizmu. Później, opierając się na ustaleniach z ostatniej książki autora, Border as Method, or, the Multiplication of Labour (napisanej razem z Brettem Neilsonem), przechodzi do namysłu nad znaczeniem upowszechnienia się granic w epoce globalizacji z perspektywy „późnego” kapitalizmu. W ostatniej części autor skupia się na podmiotowym wymiarze polityki migracji, dostarczając w tym kontekście wielu przykładów z różnych części świata (w tym z regionu Pacyfiku).
\end{abstract}

Słowa kluczowe: migracje, granica, multiplikacja pracy, późny kapitalizm, mobilność

\footnotetext{
1 Prezentowany tekst został wygłoszony w trakcie konferencji zorganizowanej przez University of Victoria „Migration \& Late Capitalism: Critical Intersections with the Asia-Pacific and Beyond” (11-13 lipca 2015) - i opublikowany w czasopiśmie naukowym „Migration, Mobility, \& Displacement” 2015, no. 2(1) na licencji Creative Commons Uznanie autorstwa-Użycie niekomercyjne 4.0 [przyp. tłum.].
} 
Chciałbym rozpoczać swój wywód od podziękowań dla organizatorów konferencji za zaproszenie mnie do wygłoszenia wykładu plenarnego na tak stymulujący i pełen wyzwań temat. Związki migracji i kapitalizmu stanowia sedno mojej pracy naukowej od dobrych kilku lat. Widać to zwłaszcza w mojej ostatniej książce napisanej wspólnie z Brettem Neilsonem, Border as Method, or, the Multiplication of Labour [Granica jako metoda albo multiplikacja pracy] (2013a). Zaproponowaliśmy w niej, by nie traktować granicy jedynie jako przedmiotu badań, ale dostrzec w niej również epistemologiczny punkt widzenia na napięcia i walki, które cechują przejścia do kapitalizmu na poziomie globalnym. Pragnę równocześnie dodać, że moje zainteresowanie migracją i studiami nad granicami nigdy nie wiązały się jedynie z namysłem naukowym. Już we wczesnych latach dziewięćdziesiątych byłem zaangażowany w liczne walki i pracę organizacji migranckich, a kwestia związków badań i aktywizmu - niekiedy omawiana w kategoriach „badań bojowych” (Grappi 2013; De Genova, Pickles i Mezzadra 2015, 63-64) - zawsze miała dla mnie duże znaczenie, zarówno w mojej pracy indywidualnej, jak również w wielu zespołowych projektach, w których uczestniczyłem w ciagu ostatnich kilku lat. Pozwólcie, że powołam się na przynajmniej jeden z nich, a mianowicie koordynację, wraz z Nicholasem De Genovą oraz Johnem Picklesem, zespołowego pisania w gronie siedemnastu badaczy-aktywistów, którego efektem był niedawno opublikowany tekst na łamach czasopisma „Cultural Studies” - New Keywords: Migration and Borders [Nowy stownik: Migracja i granice] (2015).

Przyjechałem do Victorii z Włoch, mając w głowie obrazy rozbitych łodzi oraz nieustających masowych morderstw dokonywanych na migrantach w regionie śródziemnomorskim. Rezonują one z podobnymi wizerunkami z różnych krajobrazów granicznych (borderscapes) na całym świecie, jak choćby z obrazami migrantów muzułmańskich, w tym ludzi z grupy Rohingja z Bangladeszu i Myanmaru zdanych na własne siły na morzu między Tajlandią, Malezją i Indonezją w maju 2015 roku. Czytając znakomitą książkę salwadorskiego dziennikarza Óskara Martineza, zatytułowaną La bestia (2014), miałem niedawno szansę raz jeszcze zmierzyć się z przerażająca idea „przemocy strukturalnej”. Kształtuje ona szlak migrantów z Ameryki Środkowej przez ,granicę wertykalną” (Aquino, Varela i Decosse 2013), jak określaja ścieżki łączące południową i północna granicę Meksyku krytyczni badacze migracji i granic z tego kraju. Powszednie wyrazy tej przemocy to morderstwa, porwania, wyzysk, gwałt czy niewola. Gdy mówię o „późnym kapitalizmie i migracji”, nie zamierzam „wyjaśniać” owej przemocy strukturalnej, oferując jakąś nową „wielką teorię". Spróbuję jednak myśleć o tych obrazach w trakcie mojego wykładu, przedstawiają one bowiem nie tylko nieakceptowalny nadmiar przemocy, ale również potężne wrażenie nieustępliwości i „niepoprawności” (określenie De Genovy), tak typowe dla ukazywanych przez nie ludzi w ruchu. Kładąc nacisk na tak zarysowany drugi aspekt, przeciwstawiam się wykorzystywaniu takich fraz jak „nadwyżka ludności” czy „ludzki śmieć” jako ikonicznych definicji kłopotliwego położenia globalnej migracji. 
Nie trzeba chyba przypominać, że przemoc, gwałt czy śmierć nie są czymś nowym w historii relacji między nowoczesnym kapitalizmem a migracją. Nowoczesny świat stworzył wiele odpowiedników transkontynentalnych szlaków (Christopher, Pybus i Rediker 2007), od handlu niewolnikami na Atlantyku po globalne geografie pracy najemnej, od transportu skazańców po zniewolenie rdzennej ludności (blackbirding) na Pacyfiku. Z najświeższych dociekań dotyczących tych wielorakich historii oraz geografii upodlenia nauczyliśmy się tego, że te ciała w ruchu nigdy nie były „potulne”. Praktyki rebelii oraz oporu przecinają historię nawet najbardziej brutalnych form „przymusowej” migracji, wciąż stanowiąc nieodłączną część doświadczeń przemieszczenia, wygnania oraz wywłaszczenia wiejskiej biedoty w wielu częściach świata. Wielorakie formy „przymusu”, wliczając w to rasizm oraz szczególne ustalenia prawne, cechują również różne historie „wolnych” migracji, które odegrały istotną rolę w epoce masowego uprzemysłowienia, od transatlantyckiej migracji między dziewiętnastym i dwudziestym wiekiem po gastarbeiterów oraz postkolonialne reżimy migracyjne w Europie Zachodniej po II wojnie światowej. A mimo wszystko to ci migranci sprowokowali rozwój radykalnych walk robotniczych, często wystawiając na próbę dobrze ugruntowane struktury ruchu pracowniczego.

Istnieje oczywiście szereg punktów widzenia, z których można spojrzeć na zarówno przeszłe, jak i teraźniejsze relacje między kapitalizmem a migracją. Przychodzą tu na myśl choćby zmieniające się geografie centrum i peryferii charakteryzujące transformacje kapitalizmu jako „systemu świata”, jak również powiązania między mobilnością kapitału a mobilnościa pracy. Nie trzeba przywoływać na tę okoliczność dobrze znanych nazwisk badaczy, którzy te perspektywy rozwinęli. Nie ma to oczywiście nic wspólnego z zaprzeczaniem ich znaczenia i produktywności, zwłaszcza w momencie, w którym rozciagnięcie łańcuchów towarów i dostaw poprzez nowe układy logistyczne w dramatyczny sposób przekształca geografie kapitalistycznego sposobu produkcji. Porozrzucane historyczne odniesienia do wielorakich napięć między przymusem a oporem, które właśnie przedstawiłem, wskazuja jednak na jeszcze inny analityczny i teoretyczny punkt widzenia. Jestem przekonany, że badanie migracji, zarówno w perspektywie historycznej, jak i współcześnie, jest strategicznym polem, dzięki któremu można zrozumieć szeroki wachlarz urządzeń, doświadczeń i konfliktów umożliwiających „spotkanie” między kapitałem i praca. Jak prawdopodobnie wiecie, choćby z późnych prac Louisa Althussera, „spotkanie” jest słowem wykorzystywanym przez Marksa w Kapitale w jego analizie relacji między kapitałem a praca. Chciałbym podkreślić istotność tego słowa, nawet jeśli współdzielę krytykę pod adresem Marksa, szczególnie tę rozwiniętą w ostatnich dwóch dekadach przez „globalnych historyków pracy”. Podważyli oni samą możliwość używania określenia „wolnej” i ustanowionej przez kontrakt pracy najemnej w znaczeniu standardowej charakterystyki stosunków zatrudnienia w ramach kapitalistycznego sposobu produkcji. 
Jak pokazałem już w innym miejscu, samą konstytucję „wolnej” pracy najemnej, która zdecydowanie określa konkretne historie kapitalizmu, należy rozumieć jako wynik walki o mobilność i możliwość jej kontrolowania (zob. np. Mezzadra 2011; Mezzadra i Neilson 2013a). Nicholas De Genova (2010, 40) podkreślił ostatnio, że wykorzystanie przez Marksa w jego definicji siły roboczej takich kategorii jak „energia”, „,wzburzenie” czy „ruch” wskazuje na znaczenie mobilności w „całokształcie uzdolnień fizycznych i duchowych, istniejących w organizmie, w żywej osobowości człowieka”, przez które rozumie zdolność do pracy (Marks 1968: 193). Utowarowienie tych „uzdolnień fizycznych i duchowych”, oznaczające produkcję siły roboczej jako towaru, jest wynikiem szerokiego zbioru procesów, walk i konfliktów. Nie dając się zredukować do założonej uprzednio „normy” wymiany kontraktowej, która ustępuje „wolnej” pracy najemnej, utowarowienie siły roboczej może przyjąć różne postaci. Praktyki, kontrole, ograniczenia oraz regulacja mobilności tworzą strategiczne pole dla rozwoju tych procesów, walk i konfliktów. Trzeba dodatkowo podkreślić, że nie są one ograniczone do mobilności geograficznej, ale moga obejmować również samą możliwość porzucenia konkretnej pracy. Znaczenie tej możliwości z punktu widzenia prawa pracy oraz kontraktów było często podkreślane przez historyków i badaczy prawa (np. Steinfeld 1991; MoulierBoutang 1998).

W naszych analizach relacji między migracjami a kapitalizmem musimy zawsze pamiętać o istnieniu podmiotowego czy wręcz autonomicznego wymiaru mobilności. Równie niezbędna jest też świadomość znaczenia regulowania migracji, często przedstawianego jako „suplement” autochtonicznej siły roboczej, która podlegać będzie filtrowaniu według konkretnych kryteriów i hierarchii na potrzeby prawnej i politycznej konstytucji „rynków pracy” (zob. np. Bauder 2006). Gdy już przedstawi się je w ten sposób, a jak sądzę, jest to zgodne z Marksowską definicją, pojęcie siły roboczej dostarcza teoretycznego i analitycznego spojrzenia na relacje między migracjami a kapitalizmem, którego nie daje się zredukować do figury homo oeconomicus. Dodajmy, że jej krytyka stała się czymś w rodzaju zdroworozsądkowego punktu wejścia dla współczesnych krytycznych badań nad migracjami. Produkcja podmiotowości powiązana z pojęciem siły roboczej wskazuje raczej na swego rodzaju strefę nierozróżnialności, gdzie nieustannie przepracowywane są same granice między gospodarką, polityką i kulturą. W różnych historycznych epokach kapitalizmu oraz w ramach specyficznych kapitalistycznych transformacji takie strefy nierozróżnialności przybierają odmienną, zasługującą na krytyczną analize postać.

Warto w tym miejscu poświęcić kilka słów na dyskusję nad konceptem „późnego kapitalizmu”, który znajduje się w tytule naszej konferencji. Trzeba sobie zdawać sprawę, że to pojęcie to, podobnie jak wszystkie inne tego rodzaju twory, ma swoją historię. Prawdopodobnie wyłoniło się ono z wczesnodwudziestowiecznych dyskusji na temat dramatycznych transformacji kapitalizmu, począwszy od jego głębokiego kryzysu w latach siedemdziesiątych 
dziewiętnastego wieku. Dyskusje te angażowały zarówno marksistowskich teoretyków w rodzaju Rudolfa Hilferdinga czy Włodzimierza Lenina, jak również burżuazyjnych badaczy społecznych w rodzaju Maxa Webera czy Wernera Sombarta. To właśnie temu ostatniemu przypisuje się ukucie pojęcia „późny kapitalizm” (w trzecim tomie jego Der moderne Kapitalismus, 1927), które zostało później podjęte i umieszczone w innym kontekście przez Ernsta Mandela, jak również przez krytycznych teoretyków ze szkoły frankfurckiej i jej epigonów w latach siedemdziesiątych dwudziestego wieku, przede wszystkim Jürgena Habermasa i Clausa Offe.

Nie ma potrzeby, by zagłębiać się tutaj w szczegóły tej konceptualnej historii, w ramach której rozwijano interesujące nas pojęcie. Działo się to zresztą wespół z lub jako krytyka innych pojęć w rodzaju „wysokorozwiniętego”, „monopolistycznego” czy „zorganizowanego kapitalizmu”, jak również „przemysłowego” czy „administrowanego społeczeństwa”. Wystarczy powiedzieć, że z jednej strony wyłonienie się pojęcia „późnego kapitalizmu” na początku dwudziestego wieku było częścią niezwykłych wysiłków na rzecz uchwycenia radykalnej nowości historycznie określonej formacji kapitalistycznej. A z drugiej pojęcie to miało pomóc w rozpoznaniu charakterystycznych cech kapitalizmu w szczytowym momencie jego przemysłowej i narodowej odmiany. Ujmując rzecz skrótowo, nie jest to już kapitalizm, z którym mierzymy się w naszej globalnej teraźniejszości. Fredric Jameson, którego można z powodzeniem uważać za główny punkt odniesienia dla współczesnego wykorzystania tego pojęcia, jest tego z pewnością świadomy. We wprowadzeniu do swojej książki o postmodernizmie pisał zresztą, że późny kapitalizm nie jest jego ,ulubionym hasłem i będzie się starał go używać zamiennie z odpowiednimi synonimami („,kapitalizm międzynarodowy”, „społeczeństwo spektaklu” lub „społeczeństwo obrazu”, „kapitalizm medialny”, „system światowy”, a nawet sam „postmodernizm”) (Jameson 2011, XIX, przekład zmieniony). Myślę, że warto podkreślić ten moment pojęciowej konfuzji i proliferacji, ponieważ wskazuje on na potrzebę dalszego badania zerwań, pęknięć i mutacji, które stanowią o nowości i odrębności współczesnego kapitalizmu.

Podsumowując w siłą rzeczy surowy i schematyczny sposób wspólne badania, które prowadziłem w ostatnich latach zwłaszcza z Neilsonem (Mezzadra i Neilson 2013b; 2015) oraz Véronicą Gago (Gago i Mezzadra 2015), stwierdziłbym, że kapitalizm przekroczył swój moment przemysłowy i obecnie cechuje go dominacja tego, co nazywam działaniami ekstrakcyjnymi. Rzecz jasna, nie negujemy tu trwałej istotności czy nawet ekspansji operacji przemysłowych na poziomie globalnym. Zmagamy się tu raczej z sytuacja, w której moment „dowodzenia” w samej konstytucji tego, co Marks zwykł nazywać „kapitałem całkowitym”, zwrócił się w stronę nowych kryteriów i logik, zarówno bezpośredniego wyzysku społecznej kooperacji oraz produkcji przestrzeni. Odpowiada za to przede wszystkim nowa skala procesów finansjeryzacji, 
Istotnym aspektem tej kapitalistycznej transformacji jest tendencja do zmiennych poziomów rozprzęgania kapitału i pracy oznaczająca, że relacja między konkretnymi wytwarzającymi podmiotami a kapitalistycznymi aktorami, którzy je wyzyskują, jest coraz bardziej zapośredniczona i przybiera formy, które są coraz trudniejsze do odtworzenia, zarówno analitycznie, jak i politycznie. Ma to szczególne znaczenie w przypadku akumulacji i pomnażania wartości przez kapitał finansowy (co często dyskutowane jest jako problem „Źródeł” wartości finansowych). Jestem przekonany, że jedno z najważniejszych zadań dla krytyki współczesnego kapitalizmu leży dokładnie w zrozumieniu wielorakich, różnorodnych i hierarchicznych sposobów, w jakie kapitał finansowy przenika społeczną kooperację, szerząc w jej obrębie swoją własną „racjonalność” (szczególnie za pośrednictwem logiki długu), jednocześnie splatając się i synchronizując z innymi formami kapitalistycznego wyzysku. Radykalna heterogeniczność pracy (zarówno ujmowana z punktu widzenia swojej podmiotowej konstytucji, jak i regulacji, kontroli czy wyzysku), którą wspólnie z Brettem Neilsonem usiłowaliśmy uchwycić z użyciem pojęcia „multiplikacji pracy”, osiaga swoje pełne znaczenie właśnie na gruncie tej ramy [analitycznej].

Rola migracji w takich procesach multiplikacji, podkreślmy to ponownie, jest fundamentalna. Cechuje je bowiem: przemieszczenie centralności „wolnej” pracy najemnej w organizacji rynków pracy, co pozwala im wykroczyć poza określenia typu „dualny” czy „podzielony na segmenty”, mobilizacja „kapitału ludzkiego”, który zaciera granicę między „praca”” a „działaniem”, oraz kapitalistyczny wyzysk i samopomnażanie tego, co Gago w swoich badaniach ekonomii migrantów w Ameryce Łacińskiej nazywa ludowym „witalizmem” oraz „pragmatyzmem” (Gago 2015). Tym, co ma tutaj na myśli ta autorka, jest szerokie i heterogeniczne spektrum nieformalnych, a często także zakorzenionych we wspólnocie aktywności ekonomicznych, które wspierają materialną reprodukcję sieci migrantów i transnarodowych przestrzeni oraz stają się coraz bardziej zintegrowane z obiegami kapitalistycznego pomnażania wartości w Ameryce Łacińskiej i innych miejscach na świecie. Finansjeryzacja tych ludowych i migranckich gospodarek jest pod tym względem szczególnie ważna.

Wiem, że to, co przed chwila przytoczyłem, może brzmieć abstrakcyjnie, a nawet nieco mgliście. Do tej pory podsumowałem zestaw hipotez badawczych, które zasługuja na dalsze teoretyczne i analityczne rozwinięcie. Ogromne znaczenie ma tu jednak dla mnie wskazanie na bardziej ogólną ramę, w obrębie której usiłuję nadać sens współczesnej reorganizacji relacji między kapitalizmem a migracja. $\mathrm{Na}$ poziomie globalnym, co jasne, reorganizacja ta jest daleka od homogeniczności i gładkości. Jestem jednak przekonany, że możemy rozpoznać zestaw trendów, które „przekładaja się” na najróżniejsze sposoby w różnych kontekstach, jednocześnie pozostając w zgodzie z ogólną ramą którą właśnie zaprezentowałem. Współczesny kapitalizm, właśnie z powodu hegemonii finansów oraz 
dominacji tego, co nazywam „działaniami ekstrakcyjnymi”, wspiera się na totalnej mobilizacji podmiotowych zdolności i zachowań - „w grę wchodzi tu cały zespół fizycznych i psychicznych czynników, które sprawiaja, że ktoś potrafi zdobyć płacę", by przytoczyć omówienie neoliberalnego pojęcia „kapitału ludzkiego” przez Michela Foucaulta (2011, 229).

Pojęcie to nadal kształtuje różne formy polityki społecznej i gospodarczej prowadzonej na rozmaitych geograficznych skalach, naruszając ustanowione formy regulowania pracy i wzmagając ogólne warunki niepewności i prekarności. Przyczynia się także do dalszej dywersyfikacji w obszarze pola ludzkiej aktywności przedstawianego i wyzyskiwanego przez kapitał jako „źródło wartości”. Sam Foucault podkreślał znaczenie mobilności i migracji dla teorii „kapitału ludzkiego”, które maja na celu kodowanie „materialnych” i „psychologicznych” kosztów migracji jako inwestycji. Wyrastający stąd obraz migranta jako „inwestora” (Foucault 2011, 236) znajduje poczesne miejsce w dzisiejszych teoriach i praktykach „zarządzania migracjami”, wypracowywanych i promowanych przez takich globalnych aktorów jak Międzynarodowa Organizacja ds. Migracji [International Organization for Migration], którzy odgrywają coraz bardziej znaczące role w projektowaniu i wprowadzaniu polityki migracyjnej (Geiger i Pécoud 2014). Proponuję rozumieć takie „przekładanie” neoliberalnego pojęcia „kapitału ludzkiego” na potrzeby pola „zarządzania migracjami” jako próbę odczytywania trwałych turbulencji, autonomii i uporu migracji, jej niepoddających się rządzeniu momentów wolności i ekscesu z typowej dla kapitału perspektywy pomnażania wartości.

Dywersyfikacja wzorców i doświadczeń migracyjnych, rozciąganie sieci migranckich, multiplikacja tego, co w studiach nad migracjami nazywamy „nowymi miejscami docelowymi imigrantów" (Winders 2014), przestrzenny i czasowy tumult, który cechuje współczesną migrację na poziomie globalnym, w rzeczywistości korespondują ze stałą mobilizacją podmiotowych energii i potencjałów. Proces ten radykalnie przekształca i kwestionuje ustanowione formy życia pod presją materialnych warunków deprywacji i wywłaszczenia, ale również podmiotowego ruchu w stronę otwierania nowych przestrzeni wolności i równości. Najbardziej wymowne opisy tych napięć i konfliktów zawdzięczamy prawdopodobnie badaczkom feministycznym, bowiem zjawiska te przybieraja szczególnie wyraźny kształt w ramach współczesnych procesów „feminizacji migracji”. Odwołam się do zaledwie jednego niedawnego przykładu. Ayşe Akalin w swoich badaniach nad pracą domową i opiekuńczą wykonywaną przez migrantów w Turcji stwierdziła ostatnio, że rozciąanie „globalnego łańcucha opieki” oraz zwiększenie ilości kobiet wśród migrantów, które przenoszą się w poszukiwaniu tego rodzaju zatrudnienia, „powinien być ujmowany w kontekście wszechobecnego żądania, by wyciagać z nich potencjał związany ze szczególnym zestawem kreatywnych zdolności, który okazuje się rezultatem ich mobilności” (Akalin 2015, 67). Kobieca mobilność jest w ten sposób przekładana poprzez działanie mnogich granic i urządzeń 
kontrolnych na uogólniona „dostępność” ich żywej pracy, która w wielu wypadkach zbiega się z karceralnymi trybami „zamieszkiwania w miejscu pracy” jako praktykami wspieranymi przez ich „nieregularny” status.

Dramatyczne napięcie między mobilnością a jej ograniczeniem wyrasta w samym sercu tego, co wiele badaczek analizuje w kategoriach urządzania migracji (governmentality of migration) (zob. np. Tazzioli 2015, 47-49; Walters 2015b). Myślę, że takie napięcie stawia przed nami pojęciowy i analityczny wątek, za którym musimy podążać w naszym badaniu stosunków między migracją i współczesnym kapitalizmem. W grę wchodzi tu próba czynienia mobilności produkcyjna, a zatem problem charakterystyczny dla całej historii kapitalizmu. Trzeba jednak również podkreślić, że napięcie między mobilnością i jej ograniczaniem jest dzisiaj radykalnie różnorodne i heterogeniczne, stąd bardzo daleko mu do wpisywania się w standardowe formy regulacji i zatrudnienia.

Jeśli mamy dziś do czynienia z jakimś wspólnym trendem $\mathrm{w}$ ramach polityki migracyjnej w wielu miejscach na świecie, polega on właśnie na multiplikacji i dywersyfikacji schematów rekrutacji i rodzajów wiz, które mają na celu zakodowanie pozycji indywidualnych migrantów zgodnie z ich zakładanymi „umiejętnościami”, jak również narodowością, językiem, kryteriami kulturowymi i religijnymi. Trend ten stał się jeszcze silniejszy i wyraźniej ugruntowany w wyniku globalnego kryzysu ekonomicznego z 2007 i 2008 roku.

Mamy już za sobą czasy, w których polityka migracyjna rozgrywała się wokół centralnej, pojedynczej figury, jak w przypadku przemysłowego gastarbaitera w RFN po II wojnie światowej. Podobnie rzecz ma się z dużej skali programami „przeszczepiania” pracy związanymi z procesami masowego uprzemysłowienia nowoczesnej Azji Wschodniej. Xiang Biao (2012) w swoich badaniach nad „przeszczepami” pracy chińskich migrantów w Singapurze, Korei Południowej i Japonii podkreślał istnienie trendu dotyczącego wyłonienia się „,sektora specyficznych polityk migracyjnych”, który rości sobie pretensje do rozpoznawania „bez cienia wattpliwości”, kiedy i gdzie zamierzaja pracować migranci. Jak pokazaliśmy razem z Brettem Neilsonem w Border as Method, odpowiada to fantazji migracji „dokładnie na czas” (,just-in-time”) i „w danym punkcie” (,to-the-point”) kształtującej ewolucję polityki migracyjnej $\mathrm{w}$ wielu miejscach na świecie zgodnie z ideałem, który da się ostatecznie opisać w terminach indywidualizacji kontroli migracji.

Oczywiście fantazja pozostaje fantazją, a ideał ideałem. Niemniej pozwalają nam one uchwycić pewne tendencje i procesy, które dookreślaja różnorodne współczesne przejawy napięcia między mobilnością a jej ograniczaniem, o których mowa była wyżej. Synchronizacja ruchu migracji, nawet indywidualnych migrantów, z elastyczną przestrzennością i czasowością współczesnej produkcji kapitalistycznej wymaga upowszechnienia kontroli i multiplikacji schematów rekrutacyjnych, które maja zwykle na celu instytucjonalizację tymczasowości jako zwyczajowej cechy migracji, rezonującej z uogólnionymi warunkami niepewności i prekarności 
zatrudnienia. Ważna praca zbiorowa opublikowana w 2014 roku w Kanadzie, Liberating Temporariness? [Wyz̨olic tymczasowośc??], omawia konsekwencje, jakie niesie dla badań i polityki migracyjnej przesunięcie na gruncie standardu „trwałości”, który jak pisze w swoim tekście Parvati Raghuram, jawił się przez lata jako „święty Graal w oczach teoretyków migracji niezależnie od opcji politycznej” (Raghuram 2014, 178). Takie pojęcie jak ,integracja”, które kształtuje zwykle także swoją drugą stronę, czyli kategorię „ekskluzji”, powinno ustapić na rzecz szczegółowej analizy rozmaitych form przestrzennych aranżacji i czasowych niuansów tego, co razem z Neilsonem nazwaliśmy „różnicującą inkluzją, jak również konfliktów i napięć, które rozgrywaja się nawet na polu doświadczeń i praktyk tymczasowości. Multiplikacja granic, którą mapujemy w Border as Method, musi być rozumiana również z tej perspektywy. Warto przy tym podkreślić, że zwykle przybierają one postać procesów segregacji migrantów, których kondycję konstruuje się jako tymczasową. Istnieje też architektura segregacji, o której pisze się dziś na różne sposoby na czele z badaniami nad architekturą detencji, kwestią tak żywo opisywaną i krytykowaną przez inną uczestniczkę tej konferencji, Tings Chak. Pomyślmy tylko o osiedlach grodzonych dla pracowników-migrantów w ramach systemu kafala w krajach nad Zatoką Perską, o chińskim dormitoryjnym reżimie pracy dla migrantów wewnętrznych w ramach systemu bukou, o slumsach i tekstylnych fabrykach potu [sweatshops] w Buenos Aires, w których żyją i pracują migranci z Boliwii lub włoskich obozach dla migrantów-robotników rolnych żyjących tam w, [łagodnie rzecz ujmując], „nieformalnych” warunkach. Napięcie między mobilnością i jej ograniczaniem zyskuje w tym wypadku szczególnie ostry kształt.

Pokawałkowana czasowość migracji stanowi nieodłączną czesść nowej formy uprzestrzennienia procesu formowania klas, na co wskazuja w heterogeniczny, lecz żywy sposób przywołane wyżej przykłady. Adam Hanieh, pisząc o warunkach pracy migrantów w Zatoce, podkreślał w tym kontekście potrzebę przezwyciężenia wszelkich form „metodologicznego nacjonalizmu” w analizach formacji i składu klasowego. Bardzo skutecznie pokazał, jak dynamika tego regionu, zaliczając do niego oczywiście Azję Południową, stała się wewnętrznym elementem składu klasy robotniczej w Zatoce, biorąc pod uwagę nie tylko „tych, którzy mieli okazję znaleźć się wewnątrz jego granic”, ale także „ogromną liczbę potencjalnych pracowników, którzy tworzą rezerwę siły roboczej w Zatoce” (Hanieh 2015, 67). Abstrahując od osobliwości sytuacji w omawianym regionie, jestem przekonany, że współczesna migracja, gdy już zanalizujemy konstytutywne dla niej napięcie pomiędzy mobilnością i jej ograniczaniem z perspektywy jego koordynatów przestrzennych i czasowych, pozwoli nam pojmować formowanie klas jako otwarty proces. Otwiera to także przestrzeń, w której da się produktywnie analizować związane z tym procesem konflikty i walki (zamiast wyłącznie ruchów i kondycji już ukonstytuowanej klasy). 
Wspomniany proces formowania klas dotyczy całego mnóstwa aktorów, usprawniających, jak również zakłócających ruch migrantów, wydobywając z niego wartość, na długo zanim migranci wejdą w konkretne stosunki zatrudnienia. „Praktyki nastawione na pozyskiwanie renty" typowe dla obywateli z krajów Zatoki Perskiej, którzy obierają za podstawę swojego działania system kafala (i własny uprzywilejowany status obywatelski), czerpiąc dzięki temu zysk poprzez dalsze rozciaganie stosunku zatrudnienia (AlShebabi 2015, 35), moga być ujmowane jako skrajny przykład proliferacji logiki renty w ramach całego procesu migracyjnego. William Walters, w swoim wykładzie „Where are the Missing Vehicles” [„Gdzie się podziały brakujące pojazdy"], wyrażał podobnego rodzaju przekonanie w następujący sposób: „należy poświęcić znacznie więcej uwagi w krytycznych badaniach migracji środkom transportu i ich trasom" (Walters 2012, 9). Idąc tym tropem (zob. również Walters 2015a), myślę, że trzeba dziś badać stosunki zachodzące między migracją i współczesnym kapitalizmem także z punktu widzenia tego, co można nazwać logistyką i infrastrukturą migracji. Mowa tu o pojęciach, które pojawiły się ostatnio w słowniku krytycznych badań kapitalizmu i globalizacji. Zdaniem geografki Deborah Cowen $(2014,10)$ „logistyka to motor napędowy stojący za transformacjami czasu, przestrzeni i terytoriów, dzięki którym dochodzi do globalizacji i zmian w systemach prawnych".

Nie wchodząc w szczegóły analizy Cowen, możemy stwierdzić, że mediowanie mobilności, kanalizowanie [przepływów] i dystrybucja migrantów poprzez interwencję ludzi i infrastruktury logistycznej stanowią kluczowe aspekty procesu i dynamiki współczesnej migracji. Nie muszę dodawać, że nie oznajmiam tu niczego specjalnie nowego. Stefano Harney i Fred Moten (2013) wskazywali kilka lat temu na ,trasę transportu niewolników z Afryki do Ameryki” jako kluczowy obszar wyłaniania się nowoczesnej logistyki. Jednak skala, czasowość, techniki, „racjonalność” technologiczna i ekonomiczna tej mediacji wydają się dla mnie bezprecedensowe. Owe nowe formy, procedury i technologie pośredniczące na gruncie społecznego stosunku kapitału pomnażaja i rozpowszechniaja momenty zderzeń i antagonizmu w ramach całego procesu migracji. Daleko im zatem do splatania aktorów i sieci w ramach gładkich procesów mobilności. „Logistyczne spojrzenie” na migracje byłoby pomocne w rzucaniu światła na wielorakie wymiary, skale i formy czasowości tych momentów.

Badania skupione na nadzorze i kontroli często uwypuklały kwestię narodzin migracyjnego „biznesu” i „przemysłu”, w których partycypuja tak legalni, jak i nielegalni aktorzy, dzieląc zyski będące efektem restryktywnego regulowania migracji (zob. np. Rodier 2012). Poszerzając zakres tych badań, Johan Lindquist i Xiang Biao zaproponowali pojęcie „infrastruktury migracji”, które dało im możliwość uporania się z wynikami badań etnograficznych na temat „niewykwalifikowanej migracji zarobkowej” w Indonezji i Chinach. „Migracja zarobkowa ulega intensywnej mediacji”, pisali Lindquist i Xiang (2014, 124), „w stopniu większym niż kiedykolwiek wcześniej”. Wyróżniając pięć wymiarów „,infrastruktury 
migracji” - handlowy, regulacyjny, technologiczny, humanitarny i społeczny - autorzy ci zwracali szczególną uwagę na rolę odgrywaną w ramach procesu migracji przez szeroką gamę rekrutacyjnych pośredników. I chociaż biorą pod uwagę trwałe znaczenie granic narodowych dla regulowania migracji, podkreślają też rolę „bardziej ekspansywnych form mediacji infrastruktury" w celu kształtowania kanałów i korytarzy mobilności, w których migranci sa zwykle „wprawiani w ruch przez innych” (Lindquist i Xiang 2014, 131).

Powstające w ten sposób logistyczne przestrzenie migracji są kluczowe dla organizacji „spotkań” między kapitałem i pracą w sytuacji opisywanej jako rozciaganie, uelastycznienie i outsourcing produkcji, o czym mówiłem wcześniej, odwołując się do różnych stopni „rozprzęgania” kapitału i pracy. Stawką w grze pozostaje tu po raz kolejny napięcie między mobilnością a jej ograniczaniem. Jak pokazują niezliczone wywiady, agencje rekrutacyjne i inne formy pośrednictwa odgrywają dziś fundamentalne role w procesie przywiązania migrantów do konkretnych, zazwyczaj tymczasowych form zatrudnienia, radykalnie ograniczając (np. poprzez konfiskatę paszportów) ich przestrzenną jak również rynkową mobilność (zob. np. Rota 2015). Pojęcie „czasu terminowania” (indentured time) użyte w referacie Shanti Robertson ma tutaj szczególnie dużą wartość. Co więcej, opisywane tu przestrzenie logistyczne są również przestrzeniami wydobywania wartości i pomnażania kapitału z punktu widzenia wielorakich aktorów, ponownie legalnych i nielegalnych, wliczając w to przemytników i handlarzy ludźmi, którzy, jak podkreślają ostatnie badania, są zwykle na wiele sposobów połączeni ze „specjalistami oferującymi transport, pomoc w imigracji lub usługi związane z zatrudnieniem” (Townsend i Oomen 2015, 9). Takie przestrzenie logistyczne są kształtowane przez logikę renty, pożyczki i długu, która w wielu częściach świata reprodukuje widma umów terminatorskich czy systemu przymusowej pracy zwanej peonażem. Przeplatają się, co więcej, $z$ sieciami objętymi zaawansowanym procesem finansjeryzacji, jak też z nieformalnymi sieciami, w których cyrkuluja przekazy pieniężne migrantów. Równocześnie są to przestrzenie walki, w których może się skrystalizować ostatni z pięciu wymiarów infrastruktury migracji wyróżnionych przez Lindquista i Xianga (społeczny, utożsamiony z „sieciami migrantów”). Dzieje się to pod postacią zestawu zasobów dla oporu i negocjacji, który przeciera szlak dla „mobilnych dóbr wspólnych”. Dimitris Parsanoglou, Nicos Trimikliniotis i Vassilis Tsianos $(2015,9)$ przedstawiaja je jako ,zasadniczą zdobycz będąca efektem kolektywnej władzy przekształcania świata przez ludzi w ruchu".

Podsumowując mój wywód, chciałbym podkreślić, że napięcie między mobilnością i jej ograniczaniem charakterystyczne dla globalnej historii kapitalizmu przybiera dzisiaj szczególną postać, co staje się jeszcze wyraźniejsze w następstwie globalnego kryzysu ekonomicznego z lat 2007-2008. Próby zatamowania, skanalizowania czy waloryzacji burzliwej i autonomicznej migracji, odkrywania w jej niepoddającym się rządzeniu ciele witalnych umiejętności, zdolności i potencjałów dla celów pomnażania wartości kapitału idą ręka w rękę 
z bardziej ogólnymi procesami uelastyczniania produkcji, rozbijania ustalonych formacji pracy, obywatelstwa i związanych z nim praw, jak również z multiplikacją pracy. Wyrastające stąd załamanie czasowych i przestrzennych koordynatów migracji, dywersyfikacja schematów migracyjnych, proliferacja granic, coraz bardziej intensywna mediacja dokonująca się w ramach obiegów logistycznych na gruncie, „infrastruktury migracji” muszą być rozumiane jako kluczowe aspekty produkcji siły roboczej. Dzieje się to w ramach globalnej sytuacji, w której kapitalizm reorganizuje swoje funkcjonowanie w oderwaniu od logiki i „,racjonalności” typowej dla swojej przemysłowej i narodowej odmiany. Szczególnie znaczące są tu transnarodowe i transkontynentalne skale formowania klas. Ujmując pojęcie siły roboczej z punktu widzenia produkcji podmiotowości, starałem się zaproponować taką analizę stosunków między migracją i współczesnym kapitalizmem, która wymyka się rozmaitym uproszczeniom i pułapkom typowym dla tradycyjnych teorii liberalnych i marksistowskich, podkreślających centralność pracy z wykorzystaniem figury homo oeconomicus.

Migracja pozostaje dziś strategicznym polem badań dla wszystkich tych, którzy próbuja zrozumieć, w zlokalizowany i ugruntowany sposób, skład tego, co za Marksem określamy jako żywa praca. Pojęcie to stawia przed nami szczególne wyzwania, zwłaszcza gdy zdać sobie sprawę, że jesteśmy dziś konfrontowani z potężnymi procesami, które coraz mocniej wiążą rozróżnienie ,życia” i „pracy” z kwestią przymusu. Podczas gdy migracja, tak w związku z dynamiką podmiotową, jak i sposobami jej „zarządzania”, stanowi potężną moc heterogenizacji składu żywej pracy, doświadczenia, ruchy i walki migrantów zgrywaja się podobnymi zjawiskami dotykającymi innych pracujących podmiotów. Tych samych, którzy rozsadzili samą teoretyczną i polityczną możliwość traktowania klasy robotniczej jako czegoś homogenicznego. Równocześnie takie doświadczenia, ruchy i walki czynią jeszcze pilniejszym zadanie wypracowania nowych form wspólnotowości, solidarności i organizacji walk w epoce kapitalizmu finansowego i multiplikacji pracy.

Przeto:yyli: Piotr Juskowiak i Krystian S zadkowski 


\section{Wykaz literatury}

Akalin, Ayşe. 2015. „Motherhood as Value of Labour”. Australian Feminist Studies 30.83.

AlShebabi, Omar. 2015. „Histories of Migration to the Gulf”. W Khalaf, Abdulhadi, Omar AlShebabi i Adam Hanieh (red.). Transit States: Labour, Migration \& Citizenship in the Gulf. London: Pluto Press.

Aquino, Alejandra, Amarela Varela i Frédéric Décosse (red.). 2013. Desafiando fronteras: Control de movilidad y experiencias migratorias en contexto capitalista. Oaxaca: Frontera Press/Sur.

Bauder, Harald. 2006, Labour Movement: How Migration Regulates Labour Markets. New York: Oxford University Press.

Christopher, Emma, Cassandra Pybus i Markus Rediker (red.). 2007. Many Middle Passages: Forced Migration and the Making of the Modern World. Berkeley: University of California Press.

Cowen, Deborah. 2014. The Deadly Life of Logistics: Mapping Violence in Global Trade. London: University of Minnesota Press.

De Genova, Nicholas, Sandro Mezzadra i John Pickles (red.). 2015. „New Keywords: Migration and Borders". Cultural Studies 29.1.

De Genova, Nicholas. 2010. „The Deportation Regime: Sovereignty, Space, and the Freedom of Movement". W De Genova, Nicholas i Nathalie Peutz (red.). The Deportation Regime: Sovereignty, Space and the Freedom of Movement. Durham: Duke University Press.

Foucault, Michel 2011. Narodziny biopolityki. Tłum. Michał Herer. Warszawa: WN PWN.

Gago, Véronica. 2015. La razón neoliberal: Economias barrocas y pragmática popula. Buenos Aires: Tinta Limón.

Geiger, Martin i Antoine Pécoud. 2014. „International Organizations and the Politics of Migration". Journal of Ethnic and Migration Studies 40.6.

Grappi, Giorgio. 2013. „Three Problems Without a Solution: the Militant Research Conundrum and the Social Condition of Migration". Postcolonial Studies 16.3.

Hanieh, Adam. 2015. „Overcoming Methodological Nationalism: Spatial Perspectives on Migration to the Gulf Arab States". W Khalaf, Abdulhadi, Omar AlShebabi i Adam Hanieh (red.). Transit States: Labour, Migration \& Citizenship in the Gulf. London: Pluto Press.

Harney, Stefano i Fred Moten 2013. The Undercommons: Fugitive Planning and Black Study. New York: Autonomedia.

Jameson, Fredric. 2011. Postmoderniżm czyli logika kulturowa późnego kapitalizmu. Tłum. Maciej Płaza. Kraków: Wydawnictwo UJ.

Lindquist, Johan i Xiang Biao 2014. „Migration Infrastructure”. International Migration Review 48.1 .

Martinez, Óscar. 2014. The Beast: Riding the Rails and Dodging Narcos on the Migrant Trail. London: Verso.

Marks Karol. 1968. Kapital: Krytyka ekonomii politycznej. Ksiega I: Proces wytwarzania wartości. Warszawa: Książka i Wiedza.

Mezzadra, Sandro i Brett Neilson. 2013a. Border as Method, or the Multiplication of Labour. Durham-London: Duke University Press.

Mezzadra, Sandro i Brett Neilson. 2013b. „Extraction, Logistics, Finance: Global Crisis and the Politics of Operations". Radical Philosophy 178. 
Mezzadra, Sandro i Brett Neilson. 2015. „Operations of Capital”. South Atlantic Quarterly 114.1.

Mezzadra, Sandro i Véronica Gago. 2015. „Para una crítica de las operaciones extractivas del capital: Patrón de acumulación y luchas sociales en el tiempo de la financiarización”. Nueva sociedad 255.

Mezzadra, Sandro. 2011. „How Many Histories of Labour? Towards a Theory of Postcolonial Capitalism". Postcolonial Studies 14.2.

Moulier Boutang, Yann. 1998. De l'esclavage au salariat: Économie historique du salariat bridé. Paris: Puf.

Parsanoglou, Dimitris, Nicos Trimikliniotis i Vassilis Tsianos 2015. Mobile Commons: Migrant Digitalities and the Right to the City. London: Palgrave MacMillan.

Raghuram, Parvati. 2014. „Brain Circulation or Precarious Labour? Conceptualizing Temporariness in the UK's National Health System". W Vosko, Leah F., Valerie Preston i Robert Latham (red.). Liberating Temporariness? Migration, Work, and Citizenship in an Age of Insecurity. Montreal \& Kingston: McGill-Queen's University Press.

Rodier, Claire. 2012. Xénophobie business: A quoi servant les contrôles migratoires?. Paris: La Découverte.

Rota, Stefano. 2015. „Nel ventre del drago: Da Taiwan all'Italia le dure condizioni lavorative di due migranti filippini”. http: frontierenews.it/2015/05/nel-ventre-del-drago-lavorotaiwan/.

Steinfeld, Robert J. 1991. The Invention of Free Labour. North Carolina: University of North Carolina Press.

Tazzioli, Martina. 2015. Spaces of Governmentality: Autonomous Migration and the Arab Uprisings. London: Rowman \& Littlefield.

Townsend, Jacob i Christel Oomen 2015. Before the Boat: Understanding the Migrant Journey. Brussels: Migration Policy Institute.

Walters, William. 2012. „Where Are the Missing Vehicles? Critical Reflections on Viapolitics". http:

www.academia.edu/1823268/Where_are_the_missing_vehicles_Critical_ reflections_on_viapolitics.

Walters, William. 2015a. „Migration, Vehicles, and Politics: Three Thesis on Viapolitics”. European Journal of Social Theory 18.4.

Walters, William. 2015b. „Reflections on Migration and Governmentality”. Movements. Journal für kritische Migrations- und Grenaregimeforschung 1.1.

Winders, Jamie. 2014. „New Immigrant Destinations in Global Context”. International Migration Review 48.S1.

Xiang, Biao. 2012. „Labour Transplant: 'Point-to-Point' Transnational Labour Migration in East Asia”. South Atlantic Quarterly 111.4. 
Sandro Mezzadra - filozof polityki i wykładowca teorii politycznej na Uniwersytecie w Bolonii, współpracownik Institute of Culture and Society na University of West Sydney. Jego zainteresowania obejmuja relacje globalizacji, migracji i obywatelstwa, jak również teorię postkolonialna, współczesny kapitalizm, włoski operaizm i marksizm autonomistyczny. Autor takich książek jak: La costituzione del sociale: Il pensiero politico e giuridico di Hugo Preuss (1999); Diritto di fuga: Migrazioni, cittadinanza, globalizzazione (2006); La condizione postcoloniale: Storia e politica nel presente globale (2008) oraz Border as Method, or the Multiplication of Labor (2013, razem z Brettem Neilsonem).

\section{DANE ADRESOWE:}

Sandro Mezzadra

Università di Bologna

Dipartimento di Scienze Politiche e Sociali

Strada Maggiore 45, Bologna

EMAIL: sandro.mezzadra@unibo.it

CYTOWANIE: Mezzadra, Sandro. 2016. Co jest stawką mobilności pracy? Granice, migracje, współczesny kapitalizm. Praktyka Teoretyczna 3 (21):79-93.

DOI: $10.14746 /$ prt.2016.3.3

AUTHOR: Sandro Mezzadra

TITLE: What's at Stake in the Mobility of Labour? Borders, Migration, Contemporary Capitalism

ABSTRACT: The talk starts with a short discussion of some influential works on the mobility of labour in historical and contemporary capitalism. Drawing upon a book I recently published with Brett Neilson, Border as Method, or, the Multiplication of Labour, I then discuss the significance of the proliferation of borders in the global age from the point of view of "late" capitalism. In the last part of the talk I focus on the subjective stakes of the politics of migration, providing instances from many parts of the world (including the Asia-Pacific region).

KEYWORDS: migration, border, multiplication of labour, late capitalism, mobility 